\title{
IEAATOTUKA
}

UDC 37.015.3:356.13

DOI https://doi.org/10.24919/2308-4863/37-1-24

Yuliya ADAMCHUK,

orcid.org/0000-0002-2645-4874

Postgraduate Student of the $3^{\text {rd }}$ course

National Academy of the State Border Guard Service of Ukraine named after Bohdan Khmelnytskyi

(Khmelnytskyi,_Ukraine) ginger_2004@ukr.net

\section{CONTENT, ORGANIZATION AND METHODS OF EXPERIMENTAL WORK FOR VERIFICATION OF THE EFFECTIVENESS OF PEDAGOGICAL CONDITIONS OF READINESS FORMATION OF JUNIOR INSPECTORS OF THE BORDER GUARD SERVICE FOR PROFESSIONAL ACTIVITY AT INTERNATIONAL BORDER CROSSING POINTS}

Experimental verification of the effectiveness of pedagogical conditions of readiness formation of Junior inspectors of the border guard service for professional activity at international border crossing points, which were implemented during the training at the Main Personnel Training Center of the State Border Guard Service of Ukraine, forsaw the development of content, organization and research methods. The experiment organically combined the structural elements of the methodology, determined the stages and procedure for conducting research, studying and interpreting its results. The pedagogical experiment was conducted in the educational process of the Main Personnel Training Center of the State Border Guard Service (SBGS) of Ukraine.

The ascertaining and formative experiments were conducted during the experimental work.

The purpose of the experiment was to determine the levels of readiness formation of Junior inspectors of the border guard service for professional activity at international border crossing points, to analyze the current state of readiness of junior border inspectors based on the developed criteria at the beginning of the formative experiment, during and at the final stage. The participants in the experiment were officers of the Main Personnel Training Center of the State Border Guard Service of Ukraine, unit commanders, teaching staff and cadets.

It was defined that the pedagogical conditions of the readiness formation of junior inspectors of the border guard service for professional activity at international border crossing points, which were developed by the authors and implemented in the process of training at the Main Personnel Training Center of the State Border Guard Service of Ukraine, in general positively influenced their level of readiness formation for professional activity at international border crossing points. The generalized results of the comparative analysis and statistical verification of hypotheses using Fisher criterion make it possible to state that the studied conditions of readiness formation of junior inspectors of the border guard service for professional activity at international border crossing points have quantitatively proven advantages over the existing training methods, therefore, can be recommended to practical application in the process of training junior inspectors of the border guard service at the Main Personnel Training Center of the SBGS of Ukraine.

Experimental and control study groups were selected. The control study groups were combined into a control group and the experimental study groups - into an experimental group. The time of direct experiment was 2 years.

Key words: formation of professional readiness, professional activity, criteria, indicators, pedagogical experiment.

Юлія АДАМЧУК, orcid.org/0000-0002-2645-4874 ад 'юнкт третього курсу Національної академї Державної прикордонної служби Украӥни імені Богдана Хмельницького (Хмельницьький, Україна) ginger_2004@ukr.net

\section{ЗМІСТ, ОРГАНІЗАЦІЯ ТА МЕТОДИКА ЕКСПЕРИМЕНТАЛЬНОЇ РОБОТИ ЩОДО ПЕРЕВІРКИ ЕФЕКТИВНОСТІ ПЕДАГОГІЧНИХ УМОВ ФОРМУВАННЯ ГОТОВНОСТІ МОЛОДШИХ ІНСПЕКТОРІВ ПРИКОРДОННОЇ СЛУЖБИ ДО ПРОФЕСІЙНОЇ ДІЯЛЬНОСТІ У ПУНКТАХ ПРОПУСКУ ДЛЯ МІЖНАРОДНОГО СПОЛУЧЕННЯ}

Експериментальна перевірка ефективності педагогічних умов формування готовності молодших інспекторів прикордонної служби до професійної діяльності у пунктах пропуску для міжнародного сполучення, щьо 
реалізовувалися у процесі підготовки у Головному ичентрі підготовки особового складу Державної прикордонної служби Украӥни, передбачала розробку змісту, організаиії та методики дослідження. Проведення експерименту органічно поєднало структурні елементи методики, визначило етапи та порядок проведення дослідної роботи, вивчення та інтерпретації його результатів. Педагогічний експеримент проводився в умовах навчально-виховного процесу Головного иентру підготовки особового складу Державної прикордонної служби Украӥни. Під час експериментальної роботи було проведено констатуючий та формуючий експерименти. Метою експерименту було визначити рівні сформованості готовності молодиих інспекторів прикордонної служби до професійної діяльності у пунктах пропуску для міжнародного сполучення, проаналізувати сучасний стан готовності молодших інспекторів прикордонної служби на основі розроблених критеріїв на початку формуючого експерименту, під час його проведення та на заключному етапі. Учасниками експерименту були офічери управління Головного иентру підготовки особового складу Державної прикордонної служби України, командири підрозділів, викладацький склад та курсанти. Встановлено, щьо розроблені авторами педагогічні умови формування готовності молодших інспекторів прикордонної служби до професійної діяльності у пунктах пропуску для міжнародного сполучення, щз реалізовувалися у прочесі підготовки у Головному центрі підготовки особового складу Державної прикордонної служби України, загалом позитивно вплинули на їх рівень сформованості готовності до професійної діяльності у пунктах пропуску для міжнародного сполучення. Узагальнені результати порівняльного аналізу і статистична перевірка гіпотез за допомогою критерію Фішера дозволяють стверджувати, щьо досліджувані умови формування готовності молодших інспекторів прикордонної служби до професійної діяльності у пунктах пропуску для міжнародного сполучення мають кількісно підтверджені експериментом переваги в порівнянні 3 існуючою методикою навчання, отже, можуть бути рекомендовані до практичного застосування у процесі підготовки молодших інспекторів прикордонної служби у Головному ичентрі підготовки особового складу ДПСУ. Було обрано експериментальні та контрольні навчальні групи. Контрольні навчальні групи було об'єднано в контрольну групу, експериментальні навчальні групи - в експериментальну групу. Час безпосередньої експериментальної роботи склав 2 роки.

Ключові слова: формування професійної готовності, професійна діяльність, критеріі, показники, педагогічний експеримент.

Formulation of the problem. In order to verify developed by the author the pedagogical conditions of the readiness formation of junior inspectors of the border guard service for professional activity at international border crossing points, a pedagogical experiment was planned and conducted according to the defined program of research and experimental work.

The concepts of personality self-actualization and self-realization (A. Maslow, K. Rogers), the provisions of the theory of cognitive and creative personality activity (A. A. Bodalev, L. I. Bozhovich), theory and methods of psychological research (E. Bern, R. Burns, K. Rogers) were used to create an experimental program.

The research took into account that the experiment is a kind of research method designed to objectively and convincingly hypothesis testing, it is a clearly targeted activity that contributes to the creation and testing of new technologies for personality development. Analysis of the readiness formation of junior inspectors of the border service for professional activity at international border crossing points has become an important step in the organization of experimental research.

The peculiarity of assessment of readiness formation of junior inspectors of the border guard service for professional activity at international border crossing points is that in developing the assessment methodology the authors followed the postulate that the assessment is, firstly, the result of determining, analyzing and comparing qualitative and quantitative characteristics of the assessed subject. Being a result the assessment can be in the form of grades, generalization, conclusion. Secondly, the assessment is the process of obtaining the appropriate score. The process of obtaining an evaluative conclusion consists of the following successive stages, and can be represented as the following algorithm:

- formulation of the purpose of assessment;

- determination of the subject of assessment;

- selection of indicators which characterize the subject of assessment;

- establishment of criteria for assessing indicators;

- study of the real state of indicators and their comparison with criteria;

- formulation of the evaluative conclusion.

It should be noted it is the purpose that determines the subject of assessment, its indicators and criteria, and the study of the state of indicators, the formation of the evaluative conclusion. The assessment is mostly needed not to place cadets in prize places, but to identify problems and causes of them, to determine the contribution of teachers, commanders and cadets themselves in forming their readiness for professional activity at international border crossing points.

Research analysis. During the development of the methodology of the pedagogical experiment, the criteria for assessing the readiness formation of junior inspectors of the border guard service for professional 
activity at international border crossing points, we took into account the results of research by such scientists as L. Balahur, I. Hriaznov, V. Miroshnichenko, I. Moisieienko, I. Lipatov, Yu. Lisnichenko, V. Raiko, O. Samborska, O. Safin, O. Svetlichnyi, I. Sliusar, O. Tatarin, V. Yahupov and others.

The purpose of the article is to describe the content, organization and methods of experimental work for verification of the effectiveness of pedagogical conditions of readiness formation of junior inspectors of the border guard service for professional activity at international border crossing points.

Presenting main material. Realization of the purpose was traced through the following tasks: diagnostics of readiness levels of junior inspectors of the border guard service for professional activity at international border crossing points, approbation of the experimental technique reflecting features of author's model of readiness formation of junior inspectors of the border guard service for professional activity at international border crossing points, verification of the effectiveness of pedagogical conditions of readiness formation of junior inspectors of the border guard service for professional activity at international border crossing points.

When determining the subject of assessment, it should be taken into account that it must be comprehensive, otherwise the assessment may be erroneous. If, for example, the task is to assess the readiness of junior inspectors of the border guard service for professional activity at international border crossing points, the subject of assessment should include the following set of elements:

1) learning conditions;

2) the result of the direct influence of the teaching staff and command one on the training of cadets;

3) personal educational activity of the cadet;

4) preparedness of officers (teachers and commanders) for this work.

5) In this context, we agree with the approach of V. Raiko, who identified in his study the following requirements for the criteria:

6) objectivity, that is the reflection of the features which are inherent in the subject under study, regardless of the consciousness and will of those who study;

7) reflection of essential features of the subject;

8) stability of features;

9) connection with the goals, tasks, functions and content of a particular study.

To do this, the criterion must be sufficiently detailed, dismembered, that is contain certain components, units of measuring that make it possible to measure the formation of legal culture, to compare it with the norm. The expanded criterion is a set of basic indicators that reveal the norm, the highest level of development of the phenomenon under study. Such indicators can be simple and complex (integral), depending on the empirical values (indicators) applied to operational concepts and mathematical methods of analysis of primary information (Raiko, 2008: 307).

In our opinion, indicators are qualitative and quantitative characteristics of separate properties, states of the subject under assessment. They must be accessible for cognition and measurement. We take as an example the subject of assessing the readiness of a unit officer to organize border protection at the assigned area. Indicators that characterize the training level of the officer, the conditions for increasing it could be:

- the level of knowledge acquisition;

- the level of formation of practical skills and abilities of the officer, etc.

The choice of indicators largely depends on whether the indicator has a criterion or not. The indicator without the corresponding criterion cannot play the necessary role in an assessment. Criteria and indicators can be used for comparison with other similar results in similar spheres and under the same conditions and methods of assessment. The results obtained under different conditions can not have the same assessment.

"Criterion", translated from Greek, means "a mean of solution". In professional training its role is performed by special regulations, such as guidelines, rules, requirements, sample - all items which answer the question "how it should be", that regulates the real indicators.

The features of the criterion include:

a) the ratio of the criterion to indicators of the assessment of the subject or phenomenon;

b) direct connection with indicators;

c) duration of regularity of action;

d) compliance with the purpose of the assessment.

The criterion of the assessment of the subject is a set of criteria corresponding to indicators.

Comparison of the values of indicators that characterize the subject of assessment, with the criteria can be done in different ways. They include quantitative and qualitative comparisons, grade comparisons, combined ones. In cases when the relevant criteria are not developed for the indicators, they can be determined with the help of experts.

An assessment can be expressed in various forms: in points, in the concepts of "satisfactory", "unsatisfactory", "pass", "fail", in the form of conclusions, opinions, etc. The level of practical skills and abilities of junior inspectors of the border guard service should be assessed in the scoring system. 
The key elements in assessing the readiness of junior inspectors of border guard service are: the interest and attitude to professional activity; awareness of responsibility for their own actions and the importance of their own professional activity; possession of appropriate mental qualities; ability to reflect in assessing their own actions; ability to make decisions; psychological readiness for professional activity at international border crossing points; ability to apply the acquired professional experience; ability to operate under rapidly changing conditions; ability to self-assess their professional activity, decisions that were made, and predicting.

After compiling the list of elements, by means of the method of expert estimations the maximum percentage is being determined, and the maximum amount should not exceed $100 \%$. The next step is to determine the maximum score for indivisible transactions.

An important task of our study was to determine the initial level of readiness of junior inspectors of the border guard service for professional activity at international border crossing points in EG and CG. The implementation of this task required a preliminary explanation of indicators.

We considered the fact that the criterion expressed the most common essential feature, based on which the assessment, comparison of real psychological and pedagogical phenomena was made. Besides, the degree of recognition, qualitative formation, certainty of the criterion were expressed in specific indicators, characterized by a number of features (Hriaznov, 2004: 357).

In the scientific literature, there are several approaches to the development of criteria for assessing the various elements of formation of personality qualities. Determining the criteria for the readiness formation of junior inspectors of the border guard service for professional activity at international border crossing points, we considered the fact that it is a holistic, integrated formation, which is most effectively formed under the influence of three closely interrelated components, namely: motivation of juniors inspectors of the border guard service for professional activity at international border crossing points; the combination of formation processes of necessary professional competences, psychological and physical qualities in the course of professional training; adaptive step-by-step management of educational activity of junior inspectors of the border guard service during professional training (Lytvyn, 2014: 20). That is why we have identified three main criteria of formation: motivational criterion, psychological and activity ones.
To assess the readiness of junior inspectors of the border guard service for professional activity at international border crossing points by using the method of group expert estimations, motivational, psychological and activity criteria were determined.

Motivational criterion is determined by the following indicators:

1) formation of interest in professional activity;

2) an attitude to professional activity;

3) responsibility for one's own actions;

4) awareness of the importance of professional activity at international border crossing points.

The psychological criterion is characterized by the following indicators:

- formation of mental qualities;

- ability to reflect in assessing one's own actions;

- formation of decision-making skills;

- psychological readiness for professional activity at international border crossing points.

The activity criterion is expressed through the following indicators:

a) ability to apply the acquired professional experience;

b) ability to act under changing conditions;

c) self-assessment of one's professional activity and decisions that were made;

d) ability to predict activity at international border crossing points.

All the main criteria of assessment were thoroughly and comprehensively tested. To clarify them, the managing staff of the detachments of state border protection, managing officers of departments of the border guard service, the managing and teaching staff of the Main Personnel Training Center of the State Border Guard Service of Ukraine were interviewed.

Taken together, the defined criteria characterize the external, actually achieved state of readiness formation of junior inspectors of the border guard service for professional activity at international border crossing points. Based on them, it is possible to determine the integrated criterion (IC), which is the arithmetic mean of the indicators, motivational, psychological and activity criteria, according to the formula (Hriaznov, 2004: 254)

$$
\mathrm{IC}=\frac{C_{m c}+C_{p c}+C_{a c}}{3},
$$

where IC is an integral criterion; $\mathrm{C}_{\mathrm{mc}}$ is a motivational criterion; $\mathrm{C}_{\mathrm{pc}}$ is a psychological criterion; $\mathrm{C}_{\mathrm{ac}}$ is an activity criterion.

It is clear that the selection of these criteria is conditional. It is quite difficult to consider them 
completely and implement in practice because of their interpenetration, so in the process of experimental work attention was paid to each criterion.

An important research method is the method of expert estimations, which is based on the assumption that every integral object can be represented as a complex quantitative indicator that is as the sum of the products of the object components and corresponding weighting factors. Weighting factors reflect the impact of every component of the object on the complex quantitative indicator. The total sum of the factors, according to the rationing rule, is equal to one. The quantitative value of weighting factors was determined by a specially selected group of experts. Therefore, in the case when the integral object is the level of readiness formation of junior inspectors of the border guard service for professional activity at international border crossing points, it can be defined as a complex quantitative indicator:

$$
\mathrm{C}_{\mathrm{ef}}=\mathrm{C}_{\mathrm{w} 1} \cdot \mathrm{C}_{\mathrm{mc}}+\mathrm{C}_{\mathrm{w} 2} \cdot \mathrm{C}_{\mathrm{pc}}+\mathrm{C}_{\mathrm{w} 3} \cdot \mathrm{C}_{\mathrm{ac}} \text {, }
$$

where $\mathrm{C}_{\text {ef }}$ is the total level; $\mathrm{C}_{\mathrm{w1}}$, w2, w3 are the weighting factors of each criterion. At the same time

$$
\mathrm{C}_{\mathrm{w} 1}+\mathrm{C}_{\mathrm{w} 2}+\mathrm{C}_{\mathrm{w} 3}=1 \text {. }
$$

As a result of the survey of 235 junior inspectors of the border guard service the same values of the weighting factors for assessing the level of formation of their readiness for professional activity at international border crossing points were determined. Their meaning is accepted:

$$
\mathrm{C}_{\mathrm{w} 1}=\mathrm{C}_{\mathrm{w} 2}=\mathrm{C}_{\mathrm{w} 3}=0.33 \text {. }
$$

Based on these criteria and indicators, three levels of readiness formation of junior inspectors of the border guard service for professional activity at international border crossing points were determined.

So, defined criteria and indicators demonstrate that each of the components of the readiness formation of junior inspectors of the border guard service for professional activity at international border crossing points is an object that is diagnosed and only conventionally identified in the integral process of its formation. The criteria and their indicators taken together characterize readiness formation of junior inspectors of border guard service for professional activity at international border crossing points as a process that can and should be purposefully organized, managed and at the same time strived to achieve certain results.

Based on the study of scientists (Hashchuk, 2014, Miroshnichenko, 2019, Tatarin, 2017), analysis of the state of readiness formation of junior inspectors of the border guard service for professional activity at international border crossing points, we have scientifically substantiated three levels of this formation: high, medium, low.

During the formative experiment, the comparison of its results in the control group and the experimental one was performed separately for each of the criteria, as well as for the integral one, which is the average weighted of the set of these criteria.

Table 2 demonstrates the distribution of junior inspectors of the border guard service in the control group by the levels of training according to the set of criteria under consideration at the beginning of the experiment (first assessment).

Table 3 demonstrates the distribution of junior inspectors of the border guard service in the experimental group by the levels of training according to the set of criteria under consideration at the beginning of the experiment.

Data concerning the composition of the experimental and control groups, as well as on the experiment coverage of different categories of junior inspectors of the border guard service prove that the indicators of the experimental and control groups at the initial stage of the experiment are quite homogeneous, that makes it possible to conclude about the possibility to ensure the necessary purity of the study.

At the final stage of the pedagogical experiment, the obtained results were processed. They were generalized, systematized and theoretically analysed, compared with the results obtained using other empirical and theoretical research methods.

At the same stage the results were described, brought to the participants, the pedagogical conditions of readiness formation of junior inspectors of the border guard service for professional activities at international border crossing points were implemented in practice.

\section{Characteristics of each indicator estimates}

\begin{tabular}{|c|l|}
\hline $\begin{array}{c}\text { Score, } \\
\text { in } \\
\text { points }\end{array}$ & \multicolumn{1}{c|}{ Characteristics of the indicator } \\
\hline 3 & The indicator is developed, clearly expressed, is often found \\
\hline 2 & $\begin{array}{l}\text { The indicator is markedly expressed, but is determined not constantly, although no deviations in the negative } \\
\text { direction are observed }\end{array}$ \\
\hline 1 & The indicator is expressed, but is limitedly and inefficiently found \\
\hline
\end{tabular}


Distribution by the levels of readiness formation of junior inspectors of the border guard service

for professional activity at international border crossing points in the control group CG-1 $(\mathrm{n} 1=119)$ at the beginning of the experiment

\begin{tabular}{|l|c|c|c|c|c|c|}
\hline \multirow{2}{*}{\multicolumn{2}{c|}{ Criteria }} & \multicolumn{6}{|c|}{ Levels of readiness formation } \\
\cline { 2 - 7 } & \multicolumn{2}{|c|}{ High } & \multicolumn{2}{c|}{ medium } & \multicolumn{2}{c|}{ low } \\
\cline { 2 - 7 } & absol. & in \% & absol. & in \% & absol. & in \% \\
\hline Motivational & 14 & 12 & 64 & 54 & 41 & 34 \\
\hline Psychological & 9 & 8 & 60 & 50 & 50 & 42 \\
\hline Activity & 9 & 8 & 57 & 48 & 53 & 45 \\
\hline Integral & & 9 & & 51 & & 40 \\
\hline
\end{tabular}

Table 3

Distribution by the levels of readiness formation of junior inspectors of the border guard service for professional activity at international border crossing points in the experimental group EG-1 $(\mathrm{n} 2=116)$ at the beginning of the experiment

\begin{tabular}{|c|c|c|c|c|c|c|}
\hline \multirow{3}{*}{ Criteria } & \multicolumn{6}{|c|}{ Levels of readiness formation } \\
\hline & \multicolumn{2}{|c|}{ High } & \multicolumn{2}{|c|}{ medium } & \multicolumn{2}{|c|}{ low } \\
\hline & absol. & in \% & absol. & in \% & absol. & in \% \\
\hline Motivational & 12 & 10 & 63 & 54 & 41 & 35 \\
\hline Psychological & 9 & 8 & 59 & 51 & 48 & 41 \\
\hline Activity & 7 & 6 & 58 & 50 & 51 & 44 \\
\hline Integral & & 8 & & 52 & & 40 \\
\hline
\end{tabular}

Table 4

Distribution by the levels of readiness formation of junior inspectors of the border guard service for professional activity at international border crossing points in the control group CG-2 $(n 1=119)$ at the end of the experiment

\begin{tabular}{|l|c|c|c|c|c|c|}
\hline \multirow{2}{*}{ Criteria } & \multicolumn{6}{|c|}{ Levels of readiness formation } \\
\cline { 2 - 7 } & \multicolumn{2}{|c|}{ High } & \multicolumn{2}{c|}{ medium } & \multicolumn{2}{c|}{ low } \\
\cline { 2 - 7 } & absol. & in \% & absol. & in \% & absol. & in \% \\
\hline Motivational & 16 & 13 & 66 & 55 & 37 & 31 \\
\hline Psychological & 14 & 12 & 63 & 53 & 42 & 35 \\
\hline Activity & 11 & 9 & 65 & 55 & 43 & 36 \\
\hline Integral & & 11 & & 54 & & 34 \\
\hline
\end{tabular}

The results of our study indicate that the developed pedagogical conditions of the readiness formation of junior inspectors of the border guard service for professional activities at international border crossing points, which were implemented in the process of training at the Main Personnel Training Center of the State Border Guard Service of Ukraine, in general positively influenced the level of readiness formation of junior inspectors of the border guard service for professional activity at international border crossing points in the experimental group. This is clearly evidenced by the results presented in tables 4 and 5 .

Despite the significant changes in the level of readiness formation of junior inspectors of the border guard service for professional activity at international border crossing points in the experimental group, the obtained data were verified using a multifunctional Fisher criterion to assess the statistical significance of discrepancies.

The generalized results of the comparative analysis of the distribution by levels of readiness formation of junior inspectors of the border guard service for professional activity at international border crossing points in the control and the experimental groups at the end of the formative experiment, which are represented in figure 1, as well as statistical verification of hypotheses using Fisher criterion (empirical value of criterion $\varphi=1.71$ is into the zone of significance), let us state that the studied pedagogical conditions of readiness formation of junior inspectors of the border guard service for professional activity at international border crossing points have advantages, which are quantitatively proven within the experiment, over the existing training methods, 


\begin{tabular}{|c|c|c|c|c|c|c|}
\hline \multicolumn{7}{|c|}{$\begin{array}{l}\text { Distribution by the levels of readiness formation of junior inspectors of the border guard service } \\
\text { for professional activity at international border crossing points } \\
\text { in the experimental group EG-2 }(\mathrm{n} 2=116) \text { at the end of the experiment }\end{array}$} \\
\hline \multirow{3}{*}{ Criteria } & \multicolumn{6}{|c|}{ Levels of readiness formation } \\
\hline & \multicolumn{2}{|c|}{ high } & \multicolumn{2}{|c|}{ medium } & \multicolumn{2}{|c|}{ low } \\
\hline & absol. & in \% & absol. & absol. & in \% & absol. \\
\hline Motivational & 21 & 18 & 74 & 64 & 21 & 18 \\
\hline Psychological & 18 & 16 & 79 & 68 & 19 & 16 \\
\hline Activity & 17 & 15 & 78 & 67 & 21 & 18 \\
\hline Integral & & 16 & & 66 & & 18 \\
\hline
\end{tabular}

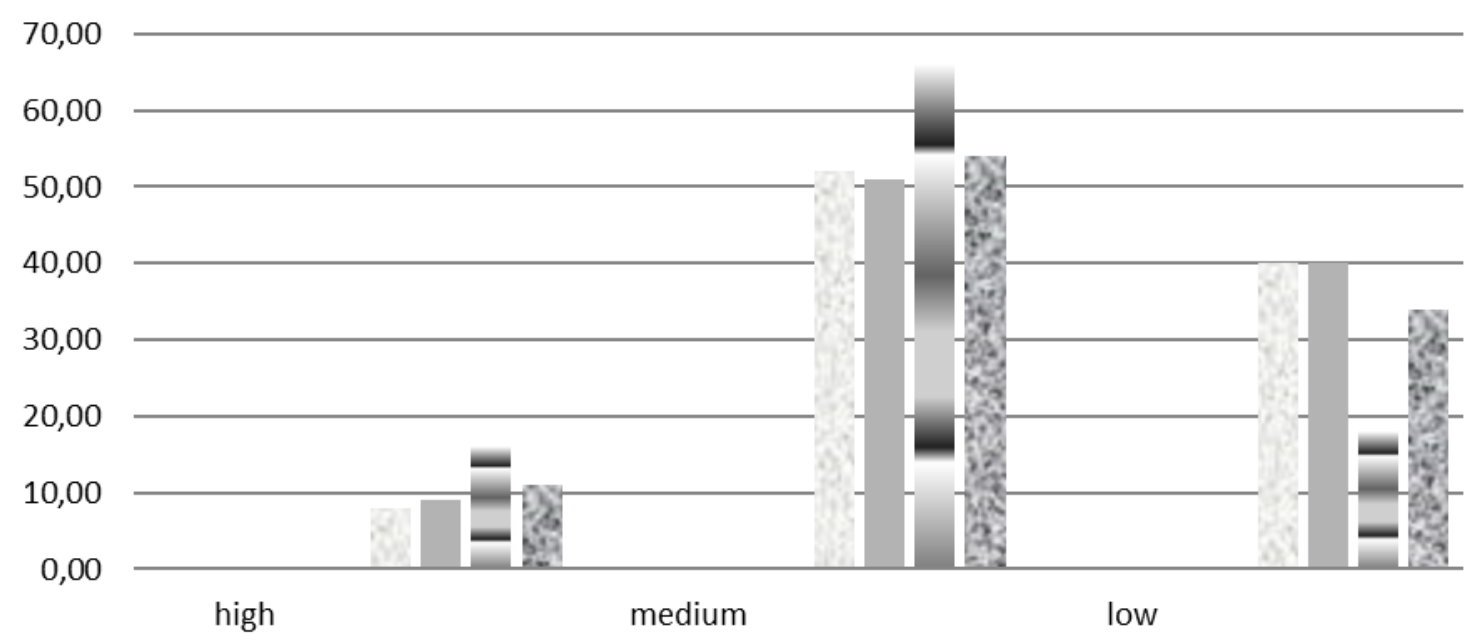

EG-1 $\square \mathrm{CG}-1 \equiv \mathrm{EG}-2$ ๑CG-2

Figure 1. Distribution by the levels of readiness formation of junior inspectors of the border guard service for professional activity at international border crossing points in the control and the experimental groups at the end of the formative experime

therefore, can be recommended to practical application in the training process of junior inspectors of the border guard service at the Main Personnel Training Center of the SBGS of Ukraine.

Conclusions. Thus, the results of the experiment, in particular the analysis of the effectiveness of the application of developed pedagogical conditions allow us to draw the following conclusions: in general, there were qualitative changes in $\mathrm{EG}$ and $\mathrm{CG}$, but significant changes were in all EGs, in contrast to CGs, where changes were insignificant; the readiness formation of junior inspectors of the border guard service for professional activity at international border crossing points in the EG is due to:

- introduction of innovative forms and methods of training junior inspectors of the border service into the educational process;
- promoting the motivation of junior inspectors of the border guard service for professional activity at international border crossing points;

- the combination of formation processes of necessary professional competences, psychological and physical qualities in the course of professional training;

- adaptive step-by-step management of educational activity of junior inspectors of the border service during professional training.

The changes that have taken place among the representatives of EG, to the greatest extent indicate a fairly high level of readiness of junior inspectors of the border guard service for professional activity at international border crossing points, who studied in the appropriate pedagogicasl conditions proposed by the author. 
Adamchuk Yu. Content, organization and methods of experimental work...

\section{BIBLIOGRAPHY}

1. Райко В. В. Теоретичні і методичні засади формування правової культури у офіцерського складу Державної прикордонної служби України : монографія. Хмельницький : Нац. акад. ДПСУ, 2008. 348 с.

2. Грязнов I. О. Система морального виховання майбутніх офіцерів-прикордонників. Хмельницький : Нац. акад. ДПСУ, 2004. 343 с.

3. Литвин А. В. Методологічні засади поняття «педагогічні умови» : на допомогу здобувачам наукового ступеня. Львів : СПОЛОМ, 2014. 76 с.

4. Татарін О. В. Визначення критеріїв, показників та рівнів сформованості готовності фахівців прикордонної служби до застосування заходів фізичного впливу. Наукові записки Вінницького державного педагогічного університету імені Михайла Коцююбинського. Серія : Педагогіка і психологія. Вінниця, 2017. Вип. 52. С. 141-146.

5. Гащук В. А. Визначення критеріїв та показників деонтологічної підготовленості майбутніх офіцерів-прикордонників. Наукові записки Вінницького державного педагогічного університету імені Михайла Коцюбинського. Серія : Педагогіка і психологія. Вінниця : ТОВ «Нілан ЛТД», 2014. Вип. 42. Ч. 1. С. 131-135.

6. Мірошніченко В., Ставицький О. Педагогічні умови формування готовності майбутніх офіцерів до використання stem-технологій в освітньому процесі. Освітній простір Украӥни. № 17. Ч. 2. (2019).

\section{REFERENCES}

1. Raiko V. V. Teoretychni i metodychni zasady formuvannia pravovoi kultury u ofitserskoho skladu Derzhavnoi prykordonnoi sluzhby Ukrainy [Theoretical and methodical principles of formation of legal culture of the officers of the State Border Guard Service of Ukraine] : monograph. Khmelnytskyi: Nats. akad. DPSU, 2008. 348 p. [in Ukrainian]

2. Hriaznov I. O. Systema moralnoho vykhovannia maibutnikh ofitseriv-prykordonnykiv [The system of moral education of future border guard officers]. Khmelnytskyi: Nats. akad. DPSU, 2004. 343 p. [in Ukrainian]

3. Lytvyn A. V. Metodolohichni zasady poniattia «pedahohichni umovy» : na dopomohu zdobuvacham naukovoho stupenya [Methodological principles of the concept of "pedagogical conditions": to help postgraduate degree seeker]. Lviv: SPOLOM, 2014. 76 p. [in Ukrainian]

4. Tatarin O. V. Vyznachennia kryteriiv, pokaznykiv ta rivniv sformovanosti hotovnosti fakhivtsiv prykordonnoi sluzhby do zastosuvannia zakhodiv fizychnoho vplyvu [Determining the criteria, indicators and levels of readiness formation of specialists of the border guard service for physical measures application]. Naukovi zapysky Vinnytskoho derzhavnoho pedahohichnoho universytetu imeni Mykhaila Kotsiubynskoho. Seriia : Pedahohika i psykholohiia. Vinnytsia, 2017. Vyp. 52. P. 141-146. [in Ukrainian]

5. Hashchuk V. A. Vyznachennia kryteriiv ta pokaznykiv deontolohichnoi pidhotovlenosti maibutnikh ofitserivprykordonnykiv [Determination of criteria and indicators of deontological proficiency of future border guard officers]. Naukovi zapysky Vinnytskoho derzhavnoho pedahohichnoho universytetu imeni Mykhaila Kotsiubynskoho. Seriia : Pedahohika i psykholohiia. Vinnytsia : TOV "Nilan LTD”, 2014. Vyp. 42. Ch. 1. P. 131-135. [in Ukrainian]

6. Miroshnichenko V., Stavytskyi O. Pedahohichni umovy formuvannia hotovnosti maibutnikh ofitseriv do vykorystannia stem-tekhnolohii v osvitnomu protsesi [Pedagogical conditions of readiness formation of future officers for stem-technologies usage in the educational process]. Osvitnii prostir Ukrainy. № 17. Ch. 2. (2019). [in Ukrainian] 